Article

\title{
Effects of Rootstock/Scion Combination and Two Irrigation Water Qualities on Cherry Tomato Yield and Postharvest Fruit Quality
}

\author{
Hiam Abu Glion ${ }^{1,2}$, Sharon Alkalai-Tuvia ${ }^{1}$, Merav Zaaroor-Presman ${ }^{1}$, Daniel Chalupowicz ${ }^{1}$, \\ Mili Zanbar ${ }^{3}$, Michal Amichai ${ }^{3}$, Shabtai Cohen ${ }^{3}$, Tsion Shemer ${ }^{3}$, Shlomo Sarig ${ }^{4}$ and \\ Elazar Fallik 1,*iD \\ 1 Department of Postharvest Science of Fresh Produce, ARO-the Volcani Center, Rishon Leziyyon 7505101, \\ Israel; hiam.abuglion@mail.huji.ac.il (H.A.G.); sharon@volcani.agri.gov.il (S.A.-T.); \\ merav.zaaroor@mail.huji.ac.il (M.Z.-P.); chalu@volcani.agri.gov.il (D.C.) \\ 2 The Robert H. Smith, Faculty of Agriculture, Food and Environment, The Hebrew University of Jerusalem, \\ P.O. Box 12, Rehovot 76100, Israel \\ 3 Ramat Negev R \& D Agricultural Research Center, Ashalim 85515, Israel; milimoprn@gmail.com (M.Z.); \\ michal.amichai@gmail.com (M.A.); sab@inter.net.il (S.C.); tsions@mop-rng.org.il (T.S.) \\ 4 Katif R \& D Center, Sdot Negev 87710, Israel; shlomosarig@gmail.com \\ * Correspondence: efallik@volcani.agri.gov.il; Tel.: +972-3968-3665
}

Received: 17 March 2019; Accepted: 15 April 2019; Published: 10 May 2019

\begin{abstract}
The aim of this research was to evaluate postharvest cherry tomato (Solanum lycopersicum (L.) Mill.) yield and fruit quality as affected by grafting and irrigation water quality in the desert region of Israel. Tomato plants (scion cv. Lorka) were grafted onto 3 commercial tomato rootstocks (Resistar, Beaufort and TRS2) and were irrigated with 2 water qualities: fresh water (electrical conductivity (EC)-1.6 dS m $\mathrm{m}^{-1}$ ) and salty water (EC-4.0 dS m $\left.\mathrm{m}^{-1}\right)$. Fresh water significantly increased fruit yield by an average of $17 \%$ and fruit size, regardless of plant grafting and rootstock, but there were no significant differences in fruit size between the water treatments. However, salty water, but not grafting, significantly improved several quality parameters of fruit stored for $12 \mathrm{~d}$ at $12{ }^{\circ} \mathrm{C}$ followed by $2 \mathrm{~d}$ at $20^{\circ} \mathrm{C}$ in simulated sea transport of produce from Israel to Europe and marketing. Fruit harvested from plants irrigated with salty water showed higher sweetness, sourness and, especially, better general taste, and significantly reduced off-flavor, compared with those irrigated with fresh water. The combination of 'Lorka' on 'Resistar' rootstock and resulted in the best external, internal, and sensory quality parameters at the end of storability and marketing simulation, while the lowest-quality parameters were in fruit harvested from 'Lorka' on 'Beaufort' rootstock.
\end{abstract}

Keywords: cherry tomato; grafting; irrigation; postharvest; shelf life; storage

\section{Introduction}

Biotic and abiotic stresses are the factors that most limit horticultural productivity worldwide [1,2]. During the present decade salinity and drought were the two main abiotic stresses in the southern part of Israel - a region that is predominantly arid and that is affected by salinity because of very low rainfall, high evapotranspiration and saline groundwater. Most of the available underground water had an electrical conductivity (EC) of about $4 \mathrm{dS} \mathrm{m}^{-1}$, which could negatively affect plant growth and yield [3]. One method of modifying plants to resist environmental stresses involves grafting commercial cultivars onto selected vigorous rootstocks [4]. Grafting is regarded as a faster alternative to the relatively slow practice of breeding for increased environmental stress tolerance in fruit and vegetables [5]; the grafted plant takes up water and nutrients from the soil more efficiently than the 
ungrafted one and retains its vitality for longer periods during the growing season [6,7]. However, various rootstock/scion combinations may have positive or negative effects on final plant or fruit size, and on fruit yield and quality, both directly after harvest and during subsequent prolonged storage [8-11].

Tomato (Solanum lycopersicum (L.) Mill.) is one of the world's most popular and widely used vegetable crops [12]. Tomato fruit contain valuable nutritional components such as vitamin $C$, as well as antioxidant activity found in carotenoid pigments, and phenolic compounds [13]. Grafted tomatoes may yield 30\% more marketable fruit per plant, but their contents of vitamin C and total phenolics may decrease significantly as a result of grafting [13]. Di Gioia et al. [14] found that vitamin C content decreased by $14-20 \%$ in the fruit of tomato plants grafted onto 'Beaufort F1' and 'Maxifort F1' compared with fruit of ungrafted plants. Savvas et al. [15] investigated the effects on fruit yield and quality of grafting a commercial tomato hybrid onto three commercial tomato rootstocks grown in a recirculating hydroponic system. 'Beaufort', 'He-Man', and 'Resistar' grown under low to moderate salt-stress conditions had enhanced titratable acidity (TA), total soluble solids (TSS), and ascorbic acid concentrations in fruit, but grafting and rootstock choice had no effect on any quality characteristics. Di Gioia et al. [14] reported similar results: fruit contents of TSS, TA, and dry matter were unaffected by grafting at any salinity level.

To the best of our knowledge, very little information is available regarding the influence of grafting in combination with various water qualities, on cherry tomato yield, and on fruit quality and sensory attributes after harvest and prolonged storage. Therefore, the goal of the present study was to evaluate cherry tomato yield and fruit size, and postharvest fruit quality, as affected by grafting and water quality in the desert region of Israel.

\section{Materials and Methods}

\subsection{Plant Materials}

The experiment was planted on 20 August 2016 on light dune soil (93\% sand) in an unheated plastic-covered greenhouse with a $30 \%$ shade net. The soil was enriched with compost at a rate of $100 \mathrm{~m}^{3} \mathrm{ha}^{-1}$, and before planting it was sterilized with Condor EC nematocide (Soiltech, Petach Tikva, Israel) and Adigan Super metam sodium (Agan Chemicals, Ashdod, Israel) at the manufacturers' recommended doses. The shade net was removed toward the end of September.

Cherry tomato (Solanum lycopersicum) cv. Lorka (Rimi, Petach Tikva, Israel) was the scion and was grafted on three commercial Israeli tomato rootstocks: 'Resistar' (Hazera Co., Brurim, Israel); 'Beaufort' (A.B. Zeraim, Airport City, Israel); and 'TRS2' (Tomatech R\&D Ltd., Rehovot, Israel). All three rootstocks were reported to form strong root systems, which improved the vigor of the grafted plants, and were resistant to Fusarium, Verticillium, Meloydogyne, and tomato mosaic virus (ToMV). Ungrafted plants served as controls. Local practices for growing in a high-wire cultivation system ( $2.5 \mathrm{~m}$ high) were applied, including: leaf pruning, side shoot removal, vine-training (four plants per meter, running on single wire, one main branch per plant, 22,000 plants/ha), and weekly canopy height adjustment.

All treatments were tested with two irrigation water qualities: Fresh-desalinated water mixed with saline water to reach an EC of $1.6 \mathrm{dS} \mathrm{m}^{-1}$; and 'Saline'-water with an EC of $4.0 \mathrm{dS} \mathrm{m}^{-1}$. Water application rates were based on daily evapotranspiration (ET) rates of the respective irrigation solutions during the growing season, as measured with lysimeters (which gave ET max). Each treatment consisted of four randomized replications. There were 32 plots in total (two water qualities and three rootstocks + non-grafted control, in four replications).

\subsection{Yield/Fruit Weight}

Market-quality yield and fruit size (weight) were evaluated about every $14 \mathrm{~d}$ from November 2016 to March 2017. Yield data included the cumulative weight of fruit (total yield) from all four replicates 
per treatment, expressed in $\mathrm{kg} \mathrm{m}^{-2}$. Fruit weight, expressed in $\mathrm{g}$ per fruit, was determined once a month during the 5 months of harvest: 30 similar fruit, based on their color (i.e., maturity stage), were picked from the middle of the bunch and weighed, and the mean fruit weight was calculated.

\subsection{Postharvest Quality Parameters}

Once monthly during five harvests, uniform clusters (ripe-on-vine) and fruit (fruit color 7-8 (light red), on a scale from 1 to 12 , where 1 = green, $6=$ pink-light red, $12=$ full red) were evaluated for external, internal and sensory parameters, immediately after harvest and after $12 \mathrm{~d}$ of storage at $12{ }^{\circ} \mathrm{C}$ with $\mathrm{RH} 93 \pm 2 \%$, followed by $2 \mathrm{~d}$ at $20^{\circ} \mathrm{C}$ (simulation for sea transport to Europe from Israel plus 2 days of marketing).

Each treatment included four open plastic containers (replications) in each of which were placed about $1 \mathrm{~kg}$ of fruit (five to six ripe-on-vine clusters). Percentage weight loss was measured for each of the four containers at the end of the cold storage and marketing simulation. Fruit firmness was measured with a Durometer (Shore Instrument and Mfg. Co., Jamaica, NY, USA) on two opposite sides of each of 10 fruit randomly taken from each container. These fruit were used to evaluate color, TSS, TA and vitamin C content. Firmness was expressed as 'units of firmness' (UF), as measured with the Durometer: a fruit was considered 'very firm'-with UF > 45; 'firm'-with UF 36-45; 'soft'-with UF 26-35; or 'very soft' - with UF < 25. Color was measured with a Chroma-Meter (Minolta, Ramsey, NJ, USA) that was calibrated against a white standard tile; two opposite sides of each tomato, taken from the firmness test, were measured and the results were expressed as Hue angle $\left(\tan ^{-b / a}\right)$. TSS (sugar content) and TA were measured in juice prepared from fresh tissue. The TSS was measured with a digital refractometer (Atago, Tokyo, Japan). The TA was measured in $5 \mathrm{~mL}$ aliquots of juice that were titrated to $\mathrm{pH} 8.1$ with $0.1 \mathrm{~N} \mathrm{NaOH}$ in a $678 \mathrm{EP} / \mathrm{KF}$ Processor automatic titrator (Metrohm AG, Herisau, Switzerland) and the results were expressed as citric acid percentage. Stem (bunch) freshness was evaluated on a scale from 1 to 3 , where $1=$ stem totally dry and brown; $2=50 \%$ of the stem fresh and green; 3 = stem totally fresh and green. Fruit abscission was determined by dropping each bunch from a height of $10 \mathrm{~cm}$ and calculating the percentage of fruit abscised from each bunch. A bunch was considered decayed once fungal mycelium appeared on it; the results were expressed as percentage of decayed bunches in each container. Vitamin C (ascorbic acid (AA)) was measured with the HI 3850 Ascorbic Acid Test Kit (Hanna Instruments, Bucharest, Romania) and the results were expressed as milligrams of vitamin C in $100 \mathrm{~g}$ fresh weight (FW) of fruit.

\subsection{Antioxidant Activity}

Antioxidant activity was evaluated by decolorization of the 2,2'-azinobis-(3-ethylbenzothiazoline6-sulphonate) $\left(\mathrm{ABTS}^{+}\right)$radical cation. The radical was generated in acidified ethanol solution to enable determination of the activities of both hydrophilic and lipophilic antioxidants. The solution was comprised of $16 \mathrm{mg}$ of $\mathrm{ABTS}^{+}$and $4 \mathrm{mg}$ of $\mathrm{K}_{2} \mathrm{O}_{8} \mathrm{~S}_{2}$ in acidified ethanol. Incubation of the reaction mixture at $45^{\circ} \mathrm{C}$ for $60 \mathrm{~min}$ was sufficient for $\mathrm{ABTS}^{+}$generation. The decolorization test was performed in plastic cuvettes by adding $10 \mu \mathrm{L}$ of test sample to $1 \mathrm{~mL}$ of acidified solution of $\mathrm{ABTS}^{+}$in ethanol, measuring the optical density at $734 \mathrm{~nm}$ after $15 \mathrm{~min}$ of incubation at room temperature, and comparing it with that of a blank sample. A $1 \mathrm{mM}$ solution of 6-hydroxy-2,5,7,8-tetramethylchroman-2-carboxylic acid (Trolox, a water-soluble derivative of vitamin E) was used as a standard, and the radical-scavenging activity of samples was expressed as Trolox equivalent antioxidant capacity (TEAC). Twenty fruit were taken from each treatment and five of them were sliced and pooled from each of four replicates. The samples were weighed, frozen in liquid $\mathrm{N}_{2}$, lyophilized and kept at $-80{ }^{\circ} \mathrm{C}$ pending further analysis. The analyses were performed in triplicate, yielding 12 readings.

\subsection{Hedonics Test}

Twenty fruit randomly taken from each treatment were cut into halves, mixed and placed on a brown glass plate, $30 \mathrm{~min}$ before sensory analysis began. Sensory quality was evaluated by a 
panel of 30-35 untrained members or students in the Department of Postharvest Science, comprising approximately equal numbers of men and women. The same panelists had conducted the hedonic tests during the harvest season. Sweetness was scored on a scale of 1-5: $1=$ no sweetness; $3=$ moderate sweetness; $5=$ very high sweetness. Sourness was scored on a scale of $1-5$ : $1=$ no sourness; $3=$ moderate sourness; $5=$ very high sourness. Off-flavor was evaluated on a scale of $0-4: 0=$ no off-flavor; 2 = moderate off-flavor; $3=$ strong off-flavor; 4 = very strong off-flavor. Texture was scored on a scale of $1-5$ : 1 = very soft and watery; $3=$ firm and slightly crispy; $5=$ very firm and crispy. General taste was scored on a scale of 1-5: $1=$ bad, $3=$ good, $5=$ excellent. At the end of the sensory analysis, panelists indicated their preferred sample. The sensory analysis was carried out for each of five harvests.

\subsection{Statistical Analysis}

All data were analyzed with the JMP 11 statistical analysis software program (SAS Institute, Duxbury, NC, USA). A two-way factorial design was used to apply analysis of variance (ANOVA, San Francisco, CA, USA) to five different harvests.

\section{Results}

Irrigation with fresh water increased fruit yield by an average of $17 \%$, compared with that obtained with saline water (Figure 1). Grafting did not affect fruit yield under irrigation with either fresh or saline water; however, with both water qualities the lowest yield was obtained with 'TRS2' rootstock (Figure 1).

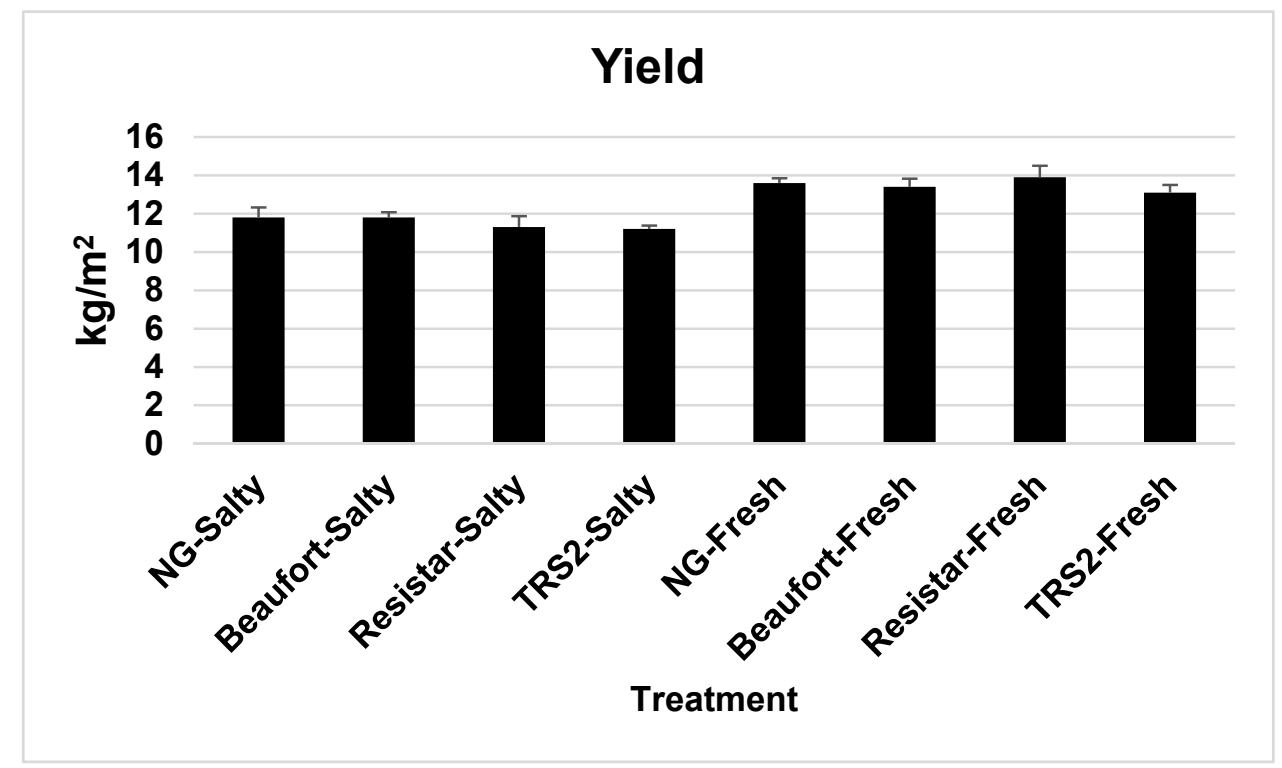

Figure 1. The influence of water quality (salty or fresh) and 'Lorka' cherry tomato on 'Beaufort', 'Resistar' or 'TRS2' rootstock on cumulative yield from October through March (NG-non-grafted) (means \pm S.E.).

Fruit weight was about $8 \%$ greater under irrigation with fresh water than with salty water, but not significantly so (Table 1). Grafting 'Lorka' on the rootstock 'Beaufort', but not on 'Resistar' or 'TRS2' increased fruit weight compared with non-grafted treatments. The highest fruit weight of $19.5 \mathrm{~g}$ was obtained in the fresh-water/'Resistar' treatment and the lowest of $16.7 \mathrm{~g}$ in the saline-water/'Resistar' treatment (Table 1). 
Table 1. The influence of water quality and grafting on mean fruit weights during five harvests. Results are expressed in $\mathrm{g} /$ fruit.

\begin{tabular}{|c|c|c|}
\hline Treatment/Water Quality & Rootstock & Fruit Weight (g) \\
\hline Saline & Non-grafted & 17.1 \\
\hline Saline & Beaufort & 18.7 \\
\hline Saline & Resistar & 16.7 \\
\hline Saline & TRS2 & 17.0 \\
\hline Fresh & Non-grafted & 19.0 \\
\hline Fresh & Beaufort & 19.2 \\
\hline Fresh & Resistar & 19.5 \\
\hline Fresh & TRS2 & 17.1 \\
\hline $\mathrm{LSD}^{\mathrm{z}}$ & & NS \\
\hline \multicolumn{3}{|c|}{ Mean weight with each water quality } \\
\hline Saline & & 17.3 \\
\hline Fresh & & 18.7 \\
\hline LSD & & NS \\
\hline \multicolumn{3}{|c|}{ Mean weight with each rootstock } \\
\hline Non-grafted & & 18.1 \\
\hline Beaufort & & 19.0 \\
\hline Resistar & & 18.0 \\
\hline TRS2 & & 17.0 \\
\hline LSD & & NS \\
\hline \multicolumn{3}{|c|}{ Table of Variance (F-value) } \\
\hline Water quality $(\mathrm{W})$ & & NS ${ }^{y}$ \\
\hline Rootstock (R) & & NS \\
\hline $\mathrm{W} \times \mathrm{R}$ & & NS \\
\hline
\end{tabular}

No significant differences were found in fruit weight loss between treatments, water qualities or rootstocks, although fruit lost more weight when irrigated with fresh water (Table 2). All rootstocks improved fruit firmness, but significant differences were found only between those on grafted 'Resistar' and non-grafted fruit. Fruit harvested from plants grafted on 'Resistar' rootstocks and irrigated with saline water were found to be the firmest, at 28.4 UF; those harvested from non-grafted plants irrigated with saline water were found to be the softest, at 23.4 UF; there was a slight interaction between water quality and rootstock in their effects on fruit firmness. Water quality significantly affected sugar content, measured as TSS: an average TSS of 5.8\% was found in fruit irrigated with saline water compared with $5.3 \%$ with fresh water; rootstock did not affect sugar content. Saline water strongly influenced fruit acidity (TA) which averaged $0.6 \%$ and $0.5 \%$, respectively, under saline- and fresh-water irrigation, whereas rootstock did not influence acidity; there was a slight interaction between water quality and rootstock in their effects on TA. No significant differences were obtained in decay development across all treatments and water qualities, although the average decay incidence was slightly higher in fruit from plants irrigated with fresh water than in those from plants irrigated with saline water: $0.9 \%$ and $0.4 \%$, respectively. Water quality significantly influenced abscission. Saline-water irrigation significantly reduced fruit abscission compared with fresh water: the saline-water/'Resistar' treatment had the lowest abscission and the fresh-water/ungrafted treatment the highest- $29.8 \%$ and $66.8 \%$, respectively. Stem freshness also was influenced by water quality: the average stem freshness of fruit irrigated with saline water was significantly better than that of those irrigated with fresh water: 2.4 and 2.3, respectively. Grafting also affected stem freshness: on all grafted plants, stem freshness was significantly better than that on non-grafted plants (Table 2). 
Table 2. Influence of water quality and grafting on 'Lorka' cherry tomato external and internal fruit-quality parameters after $12 \mathrm{~d}$ at $12{ }^{\circ} \mathrm{C}$ plus $2 \mathrm{~d}$ at $20^{\circ} \mathrm{C}$ (Means of 5 harvests).

\begin{tabular}{|c|c|c|c|c|c|c|c|c|}
\hline Water Quality & Rootstock & $\begin{array}{c}\text { Weight Loss }{ }^{\mathrm{z}} \\
(\%)\end{array}$ & $\begin{array}{l}\text { Firmness } \\
\text { (UF) } \mathrm{y}\end{array}$ & $\begin{array}{l}\text { TSS } \\
(\%)^{x}\end{array}$ & TA $(\%)^{w}$ & $\begin{array}{c}\text { Decay } \\
(\%)\end{array}$ & $\begin{array}{l}\text { Abscission } \\
(\%)\end{array}$ & $\begin{array}{c}\text { Stem } \\
\text { Freshness } \\
(1-3)^{\mathrm{v}}\end{array}$ \\
\hline Saline & $\mathrm{NG}^{\mathrm{u}}$ & 4.0 & $23.4 \mathrm{~b}^{\mathrm{t}}$ & $5.6 \mathrm{ab}$ & $0.57 \mathrm{ab}$ & 0.40 & 54.4 & 2.2 \\
\hline Saline & Beaufort & 4.5 & $24.2 \mathrm{ab}$ & $5.6 \mathrm{ab}$ & $0.58 \mathrm{ab}$ & 0.32 & 44.8 & 2.4 \\
\hline Saline & Resistar & 3.2 & $28.4 \mathrm{a}$ & $6.2 \mathrm{a}$ & $0.62 \mathrm{a}$ & 0.24 & 29.8 & 2.5 \\
\hline Saline & TRS2 & 3.5 & $25.0 \mathrm{ab}$ & $5.7 \mathrm{ab}$ & $0.52 \mathrm{bc}$ & 0.64 & 57.8 & 2.4 \\
\hline Fresh & NG & 4.8 & $24.2 \mathrm{ab}$ & $5.4 \mathrm{ab}$ & $0.46 \mathrm{c}$ & 1.08 & 66.8 & 2.2 \\
\hline Fresh & Beaufort & 4.5 & $25.4 \mathrm{ab}$ & $5.2 \mathrm{~b}$ & $0.48 \mathrm{c}$ & 1.58 & 56.6 & 2.3 \\
\hline Fresh & Resistar & 3.9 & $24.4 \mathrm{ab}$ & $5.3 \mathrm{ab}$ & $0.47 \mathrm{c}$ & 0.28 & 56.6 & 2.3 \\
\hline Fresh & TRS2 & 3.7 & $26.0 \mathrm{ab}$ & $5.2 \mathrm{a}$ & $0.48 \mathrm{c}$ & 0.60 & 54.8 & 2.3 \\
\hline LSD & & NS & 1.5 & NS & 0.02 & NS & NS & NS \\
\hline \multicolumn{9}{|c|}{ Averages for each water quality } \\
\hline Saline & & 3.78 & 25.4 & $5.8 \mathrm{a}$ & $0.6 \mathrm{a}$ & 0.4 & $46.7 \mathrm{~b}$ & $2.4 \mathrm{a}$ \\
\hline Fresh & & 4.25 & 25.0 & $5.3 \mathrm{~b}$ & $0.5 \mathrm{~b}$ & 0.9 & $58.7 \mathrm{a}$ & $2.3 \mathrm{~b}$ \\
\hline LSD & & NS & NS & 0.2 & 0.01 & NS & 5.8 & 0.03 \\
\hline \multicolumn{9}{|c|}{ Averages for each rootstock } \\
\hline NG & & 4.40 & $23.8 \mathrm{~b}$ & 5.5 & 0.5 & 0.74 & 60.6 & $2.2 \mathrm{~b}$ \\
\hline Beaufort & & 4.51 & $25.1 \mathrm{ab}$ & 5.4 & 0.5 & 0.94 & 50.7 & $2.3 \mathrm{a}$ \\
\hline Resistar & & 3.55 & $26.4 \mathrm{a}$ & 5.7 & 0.5 & 0.26 & 43.2 & $2.4 \mathrm{a}$ \\
\hline TRS2 & & 3.61 & $25.5 \mathrm{ab}$ & 5.5 & 0.5 & 0.62 & 56.3 & $2.3 \mathrm{a}$ \\
\hline LSD & & NS & 1.0 & NS & NS & NS & NS & 0.05 \\
\hline \multicolumn{9}{|c|}{ Analysis of Variance ( $p$-value) } \\
\hline Water quality & & $\mathrm{NS}^{\mathrm{s}}$ & NS & ** & $* * * *$ & NS & * & * \\
\hline Rootstock & & NS & $*$ & NS & NS & NS & NS & $* *$ \\
\hline $\mathrm{W} \times \mathrm{R}$ & & NS & * & NS & $*$ & NS & NS & NS \\
\hline
\end{tabular}

${ }^{\mathrm{z}}$ Percentage weight loss from the initial weight; ${ }^{\mathrm{y}}$ Unit of firmness (UF): $>45$ = very firm; $35-44=$ firm; $25-239=$ soft; $<24$ = very soft; ${ }^{\mathrm{x}}$ Total soluble solids (TSS): percentage of brix; ${ }^{\mathrm{w}}$ Acidity (TA): percentage of citric acid.; ${ }^{\mathrm{v}}$ Stem freshness: 1 = dry and brown stem; 2 = mainly fresh and slight brownish; 3 = fresh and green; ${ }^{\text {u }}$ Non-grafted (NG): control; ${ }^{\mathrm{t}}$ Means within columns followed by the same letter do not differ according to the Least Significant Difference Test at $p \leq 0.05 ;{ }^{*} * * *, * * *, * * *, N S$ indicate statistical significance at $p \leq 0.0001,0.001,0.01$, and 0.05 , and not significant, respectively.

A significantly higher vitamin $C$ content was found in fruit from plants irrigated with saline water than in those irrigated with fresh water: averages of 27 and $23 \mathrm{mg}$ per $100 \mathrm{~g}$ (FW), respectively (Table 3). Rootstock did not affect vitamin C content, but significantly affected lycopene content: the highest lycopene content was associated with 'Resistar' rootstock, especially with saline water, the lowest with 'Beaufort' -41 and $35.9 \mu \mathrm{g} \mathrm{g}^{-1}$ (FW), respectively. Water quality did not affect the fruit lycopene content. Neither water quality nor rootstock affected antioxidant activity in harvested fruit (Table 3).

Fruit flavor was significantly more influenced by water quality than by grafting (Table 4). Fruit from plants irrigated with saline water had greater sweetness, sourness and, especially, better general taste and significantly less off-flavor than those irrigated with fresh water. Grafting, however, significantly increased off-flavor in fruit from 'Resistar' and 'TRS2' rootstocks, whereas very little off-flavor was observed in non-grafted fruit. Neither water quality nor rootstock affected texture of harvested fruit (Table 4). 
Table 3. Influence of water quality and grafting on nutritional levels in cherry tomato fruit after storage for $12 \mathrm{~d}$ at $12{ }^{\circ} \mathrm{C}$ and $2 \mathrm{~d}$ at $20^{\circ} \mathrm{C}$ (Means of 5 harvests).

\begin{tabular}{|c|c|c|c|c|c|c|}
\hline \multicolumn{2}{|c|}{ Water Quality } & Rootstock & $\begin{array}{c}\text { Vitamin C } \\
(\mathrm{mg} / 100 \mathrm{~g} \text { FW) }\end{array}$ & \multicolumn{2}{|c|}{$\begin{array}{l}\text { Lycopene } \\
(\mu \mathrm{g} / \mathrm{g} \text { FW) }\end{array}$} & $\begin{array}{c}\text { AOX (TEAC } \\
\mu \mathrm{M} \text { TE/g) }\end{array}$ \\
\hline \multicolumn{2}{|l|}{ Saline } & $\mathrm{NG}^{\mathrm{z}}$ & 27.7 & 36.0 & & 1.0 \\
\hline \multicolumn{2}{|l|}{ Saline } & Beaufort & 27.1 & 36.5 & & 1.3 \\
\hline \multicolumn{2}{|l|}{ Saline } & Resistar & 29.5 & 42.7 & & 1.3 \\
\hline \multicolumn{2}{|l|}{ Saline } & TRS2 & 24.6 & 38.1 & & 1.2 \\
\hline \multicolumn{2}{|l|}{ Fresh } & NG & 22.4 & 37.4 & & 1.0 \\
\hline \multicolumn{2}{|l|}{ Fresh } & Beaufort & 21.8 & 35.3 & & 1.1 \\
\hline \multicolumn{2}{|l|}{ Fresh } & Resistar & 23.3 & 37.5 & & 1.0 \\
\hline \multicolumn{2}{|l|}{ Fresh } & TRS2 & 24.4 & 36.5 & & 1.1 \\
\hline \multicolumn{2}{|l|}{ LSD } & & NS & NS & & NS \\
\hline \multicolumn{7}{|c|}{ Average for each water quality } \\
\hline \multicolumn{2}{|l|}{ Saline } & & $27.2 \mathrm{a}^{\mathrm{y}}$ & \multicolumn{2}{|c|}{38.3} & 1.2 \\
\hline \multirow{2}{*}{\multicolumn{2}{|c|}{$\begin{array}{l}\text { Fresh } \\
\text { LSD }\end{array}$}} & & $22.9 \mathrm{~b}$ & \multicolumn{2}{|c|}{36.7} & 1.0 \\
\hline & & & 1.6 & \multicolumn{2}{|l|}{ NS } & NS \\
\hline \multicolumn{7}{|c|}{ Average for each rootstock } \\
\hline & & NG & 25.1 & 36.71 & & 1.0 \\
\hline & & Beaufort & 24.4 & $35.9 \mathrm{l}$ & & 1.2 \\
\hline & & Resistar & 26.4 & $40.1 \mathrm{c}$ & & 1.2 \\
\hline & & TRS2 & 24.4 & 37.31 & & 1.2 \\
\hline & & LSD & NS & 1.7 & & NS \\
\hline \multicolumn{7}{|c|}{ Analysis of Variance ( $p$-value) } \\
\hline \multirow{3}{*}{\multicolumn{2}{|c|}{$\begin{array}{l}\text { Water quality } \\
\text { Rootstock } \\
\mathrm{W} \times \mathrm{R}\end{array}$}} & & $* x$ & \multicolumn{2}{|l|}{ NS } & NS \\
\hline & & & NS & \multicolumn{2}{|l|}{$* *$} & NS \\
\hline & & & NS & \multicolumn{2}{|l|}{ NS } & NS \\
\hline \multicolumn{7}{|c|}{$\begin{array}{l}\text { Non-grafted (NG): control; }{ }^{y} \text { Means within columns followed by the same letter do not differ according to the } \\
\text { east Significant Difference Test at } p \leq 0.05 ; * * * *, * * * * *, *, \text { NS indicate statistical significance at } p \leq 0.0001,0.001 \text {, } \\
.01 \text {, and } 0.05 \text {, and not significant, respectively. }\end{array}$} \\
\hline Nater Quality & Rootstock & $\begin{array}{c}\text { Sweetness } \\
(1-5)^{z}\end{array}$ & $\begin{array}{l}\text { Sourness } \\
(1-5)^{y}\end{array}$ & $\begin{array}{l}\text { Off-Flavor } \\
(0-4)^{x}\end{array}$ & $\begin{array}{l}\text { Texture } \\
(1-5)^{w}\end{array}$ & $\begin{array}{c}\text { General Taste } \\
(1-5)^{v}\end{array}$ \\
\hline Saline & $\mathrm{NG}^{\mathrm{u}}$ & 3.0 & 2.4 & 0.4 & 3.1 & 3.3 \\
\hline Saline & Beaufort & 2.9 & 2.2 & 0.6 & 3.1 & 3.3 \\
\hline Saline & Resistar & 3.2 & 2.4 & 0.6 & 3.3 & 3.4 \\
\hline Saline & TRS2 & 3.0 & 2.3 & 0.7 & 3.4 & 3.3 \\
\hline Fresh & NG & 2.6 & 2.1 & 0.6 & 3.2 & 3.0 \\
\hline Fresh & Beaufort & 2.6 & 2.2 & 0.7 & 3.2 & 2.9 \\
\hline Fresh & Resistar & 2.5 & 2.2 & 1.0 & 3.2 & 2.8 \\
\hline Fresh & TRS2 & 2.7 & 1.7 & 0.9 & 3.2 & 2.9 \\
\hline LSD & & NS & NS & NS & NS & NS \\
\hline \multicolumn{7}{|c|}{ Averages for each water quality } \\
\hline Saline & & $3.0 \mathrm{a}$ & $2.3 \mathrm{a}$ & $0.6 \mathrm{a}$ & 3.2 & $3.3 \mathrm{a}$ \\
\hline Fresh & & $2.6 \mathrm{~b}$ & $2.0 \mathrm{~b}$ & $0.8 \mathrm{~b}$ & 3.2 & $2.9 \mathrm{~b}$ \\
\hline LSD & & 0.1 & 0.1 & 0.1 & NS & 0.1 \\
\hline
\end{tabular}


Table 4. Cont.

\begin{tabular}{|c|c|c|c|c|c|c|}
\hline Water Quality & Rootstock & $\begin{array}{c}\text { Sweetness } \\
(1-5)^{\mathrm{z}}\end{array}$ & $\begin{array}{c}\text { Sourness } \\
(1-5)^{y}\end{array}$ & $\begin{array}{l}\text { Off-Flavor } \\
(0-4)^{x}\end{array}$ & $\begin{array}{l}\text { Texture } \\
(1-5)^{w}\end{array}$ & $\begin{array}{c}\text { General Taste } \\
(1-5)^{v}\end{array}$ \\
\hline \multicolumn{7}{|c|}{ Averages for each rootstock } \\
\hline & NG & 2.8 & 2.2 & $0.5 \mathrm{~b}$ & 3.3 & 3.1 \\
\hline & Beaufort & 2.8 & 2.2 & $0.6 \mathrm{ab}$ & 3.1 & 3.1 \\
\hline & Resistar & 2.9 & 2.3 & $0.8 \mathrm{a}$ & 3.3 & 3.1 \\
\hline & TRS2 & 2.9 & 2.0 & $0.8 \mathrm{a}$ & 3.3 & 3.1 \\
\hline & LSD & NS & NS & 0.2 & NS & NS \\
\hline \multicolumn{7}{|c|}{ Analysis of Variance ( $p$-value) } \\
\hline Water quality & & $* * * \mathrm{~S}$ & ** & * & NS & $* * * *$ \\
\hline Rootstock & & NS & NS & ** & NS & NS \\
\hline $\mathrm{W} \times \mathrm{R}$ & & NS & NS & NS & NS & NS \\
\hline
\end{tabular}

${ }^{\mathrm{z}}$ Sweetness: 1-no sweetness; 3-moderate sweetness; 5-very sweet; ${ }^{\mathrm{y}}$ Sourness: 1-no sourness; 3-moderate sourness; 5 -very sour; ${ }^{\mathrm{x}}$ Off-flavor: 0 -no of flavor; 2 -moderate off-flavor; 5 -very strong off-flavor; ${ }^{\mathrm{w}}$ Texture: 1-very soft and watery; 3 -firm and slightly crispy; 5 -very firm and crispy; ${ }^{\mathrm{v}}$ General taste: 1 -bad; 3-good; 5-excellent; ${ }^{\mathrm{u}}$ Non-grafted (NG): control; ${ }^{\mathrm{t}}$ Means within columns followed by the same letter do not differ according to the Least Significant Difference Test at $p \leq 0.05 ; \mathrm{s} * * * * * * * * * * *$, NS indicate statistical significance at $p \leq 0.0001,0.001,0.01$, and 0.05 , and not significant, respectively.

\section{Discussion}

The major growing area in Israel for cherry tomato is the arid south-west of the country, where salinity and drought are two of the major abiotic stress factors. Most of the available underground water in this region is saline, with an EC about $4 \mathrm{dS} \mathrm{m}^{-1}$; and even higher in most wells. To resist these abiotic stresses, grafting can increase environmental-stress tolerance of fruit vegetables [5] and improves the vegetative growth under water qualities and quantities $[5,15]$.

Water quality can profoundly affect the yield of vegetables $[3,16]$. We have found that salinity reduced the cherry tomato yield by $17 \%$, mainly because of decreased fruit size and weight (Figure 1). The reduction in yield at high salinity can be attributed to low water content in the fruit-a result of poor uptake of highly saline water [17], or of poor photosynthesis, which decreases $\mathrm{CO}_{2}$ availability as a result of diffusion limitations [18]. In the present study grafting barely influenced fruit yield, as was reported also by Koutsika-Sotiriou and Traka-Mavrona [19]. However, Higashide et al. [20] reported that grafting increased tomato yield. Savvas et al. [16] also reported that grafting resulted in increased fruit and thus yield, when plants were exposed to low or moderate salinity in hydroponic system. This variability among reported findings demonstrates the importance of optimizing rootstock/scion combinations for each growth environment, including growing system, type of soil, day and night temperatures, and fertigation [21]. Each grafting combination should be tested under the anticipated salinity-exposure conditions before deciding on its suitability as a means to enhance the salt resistance of commercial greenhouse crops [16]. In Israel, use of rootstocks can extend the growing season to more than 10 months. However, the reason that we did not observe significant yield differences between different rootstocks using water of the same quality, was probably that plant virus infections in March-April each year shortened the growing season.

Grafting has a dramatic impact on the plant and its fruit and can affect fresh produce quality [4,11,22]. After storage for $12 \mathrm{~d}$ at $12{ }^{\circ} \mathrm{C}$ followed by $2 \mathrm{~d}$ at $20^{\circ} \mathrm{C}$, several fruit-quality parameters were significantly influenced by irrigation-water quality rather than grafting (Tables 1-3). However, the combination of 'Lorka' (scion) and 'Resistar' (rootstock) was better than other combinations with respect to some of the fruit-quality parameters after storage and shelf life simulation. Irrigating 'Lorka'/'Resistar' plants with high-salinity water resulted in increased fruit firmness and sugar and acid contents after prolonged storage. High salinity (4.0 EC) increased health-promoting substances such as vitamin $C$ and lycopene, as well, as reported also by Krumbein and Schwarz [23]. This combination also resulted in improved overall taste (Table 4). It is possible that the root system of the 'Resistar' 
rootstock was more developed, with longer and thicker roots, which improved uptake of water and nutrients during salt stress and their transfer from the soil to the fruit [24]. It is also possible that the rootstock/scion combination might influence the amounts of hormones produced in the plant, thereby affecting the sink/source relationship and the improvement in fruit quality due to grafting [6].

Irrigation with fresh water at $1.6 \mathrm{dS} \mathrm{m}^{-1}$ resulted in significantly greater fruit yield and size than water irrigation, regardless of plant grafting. On the other hand, water salinity, rather than grafting, was the more significant factor in improving several fruit-quality parameters after storage for $12 \mathrm{~d}$ at $12{ }^{\circ} \mathrm{C}$ followed by $2 \mathrm{~d}$ at $20^{\circ} \mathrm{C}$. However, fruit irrigated with high-salinity water and harvested from the combination of rootstock 'Resistar' and scion 'Lorka' had better external, internal and sensory qualities. Although the cost of a grafted tomato seedling is $1.5-2 \times$ greater than that of a conventional seedling, the possibility of introducing advantageous horticultural traits without compromising fruit characteristics has significant value [25]. Moreover, use of an appropriate rootstock/scion combination and moderately saline water can improve fruit characteristics. However, further investigation is needed to evaluate the interaction of other commercial rootstocks and scions under saline conditions on fruit quality and storability.

Author Contributions: H.A.G. was a MSc student during 2016 and 2017 and conducted most of the research; S.A.-T., M.Z.-P. and D.C. are research engineers in E.F. laboratory. They conducted and analyzed part of the experiments. E.F. supervised H.A.G. during her MSc studies, planned the research and wrote the manuscript; M.Z., M.A., S.C., T.S. carried out the greenhouse experiments and harvest during 2016 and 2017; S.S. measured fruit nutritional characteristics.

Funding: This research was supported by ICA in Israel as research number 430-0596-16/17 and was partially supported by the Israel Ministry of Agriculture and Rural Development (Eugene Kandel Knowledge Centers) as part of 'The Root of the Matter-the Root Zone Knowledge Center'. This paper is Contribution No. 831/18, from the ARO, The Volcani Center, Rishon LeZiyyon, Israel.

Conflicts of Interest: The authors declare no conflict of interest.

\section{References}

1. Colla, G.; Rouphael, Y.; Leonardi, C.; Bie, Z. Role of grafting in vegetable crops grown under saline conditions. Sci. Hortic. 2010, 127, 147-155. [CrossRef]

2. Savvas, D.; Colla, G.; Rouphael, Y.; Schwarz, D. Amelioration of heavy metal and nutrient stress in fruit vegetables by grafting. Sci. Hortic. 2010, 127, 156-161. [CrossRef]

3. Singh, S.; Grover, K.; Begna, S.; Angadi, S.; Shukla, M.; Steiner, R.; Auld, D. Physiological response of diverse origin spring safflower genotypes to salinity. J. Arid Land Stud. 2014, 24, 169-174.

4. Fallik, E.; Ilic', Z. Grafted vegetables-The influence of rootstock and scion on postharvest quality. Folia Hortic. 2014, 26, 79-90. [CrossRef]

5. Flores, F.B.; Sanchez-Bel, P.; Estan, M.T.; Martinez-Rodriguez, M.M.; Moyano, E.; Morales, B.; Campos, J.F.; Garcia-Abellan, J.O.; Egea, M.I.; Fernandez-Garcia, N.; et al. The effectiveness of grafting to improve tomato fruit quality. Sci. Hortic. 2010, 125, 211-217. [CrossRef]

6. Aloni, B.; Cohen, R.; Karni, L.; Aktas, H.; Edelstein, M. Hormonal signaling in rootstock-scion interactions. Sci. Hortic. 2010, 127, 119-126. [CrossRef]

7. Lee, J.M.; Kubota, A.C.; Tsao, S.J;; Bie, Z.; Echevarria, P.H.; Morra, L.; Oda, M. Current status of vegetable grafting: Diffusion, grafting techniques, automation. Sci. Hortic. 2010, 127, 93-105. [CrossRef]

8. Alexopoulos, A.A.; Kondylis, A.; Passam, H.C. Fruit yield and quality of watermelon in relation to grafting. J. Food Agric. Environ. 2007, 5, 178-179.

9. Bekhradi, F.; Kashi, A.; Delshad, M. Effect of three cucurbits rootstocks on vegetative and yield of 'Charleston Gray' watermelon. Int. J. Plant Prod. 2011, 5, 105-110.

10. Kyriacou, M.C.; Soteriou, G.A. Postharvest change in compositional, visual and textural quality of grafted watermelon cultivars. Acta Hortic. 2012, 934, 985-991. [CrossRef]

11. Rouphael, Y.; Schwarz, D.; Krumbein, A.; Colla, G. Impact of grafting on product quality of fruit vegetables. Sci. Hort. 2010, 127, 172-179. [CrossRef]

12. Mauromicale, G.; Longo, A.M.G.; Lo Monaco, A. The effect of organic supplementation of solarized soil on the quality of tomato fruit. Sci. Hortic. 2011, 129, 189-196. [CrossRef] 
13. Vinkovic Vrcek, I.; Samobor, V.; Bojic, M.; Medic-Saric, M.; Vukobratovic, M.; Erhatic, R.; Horvat, D.; Matotan, Z. The effect of grafting on the antioxidant properties of tomato (Solanum lycopersicum L.). Span. J. Agric. Res. 2011, 9, 844-851. [CrossRef]

14. Di Gioia, F.; Signore, A.; Serio, F.; Santamaria, P. Grafting improves tomato salinity tolerance through sodium partitioning within the shoot. Hort. Sci. 2013, 48, 855-862. [CrossRef]

15. Al-Harbi, A.; Hejazi, A.; al-Omran, A. Responses of grafted tomato (Solanum lycopersicum L.) to abiotic stresses in Saudi Arabia. Saudi J. Biol. Sci. 2017, 24, 1274-1280. [PubMed]

16. Savvas, D.; Savvas, A.; Ntatsi, G.; Ropokis, A.; Karapanos, I.; Krumbein, A.; Olympios, C. Effects of three commercial rootstocks on mineral nutrition, fruit yield, and quality of salinized tomato. J. Plant Nutr. Soil Sci. 2011, 174, 154-162. [CrossRef]

17. Zhang, P.; Senge, M.; Dai, Y. Effects of salinity stress at different growth stages on tomato growth, yield, and water-use efficiency. Commun. Soil Sci. Plant Anal. 2017, 48, 624-634. [CrossRef]

18. Flexas, J.; Diaz-Espejo, A.; Galmés, J.; Kaldenhoff, R.; Medrano, H.; Ribas-Carbo, M. Rapid variations of mesophyll conductance in response to changes in $\mathrm{CO}_{2}$ concentration around leaves. Plant Cell Environ. 2007, 30, 1284-1298. [CrossRef] [PubMed]

19. Koutsika-Sotiriou, M.; Traka-Mavrona, E. The cultivation of grafted melons in Greece, current status and prospects. Acta Hort. 2002, 579, 325-330. [CrossRef]

20. Higashide, T.; Nakano, A.; Yasuba, K. Yield and dry matter production of a Japanese tomato 'Momotaro York' are improved by grafting onto a Dutch rootstock 'Maxifort'. J. Jpn. Soc. Hort. Sci. 2014, 83, 235-243. [CrossRef]

21. Kumar, S.; Bharti, N.; Saravaiya, S.N. Vegetable grafting: A surgical approach to combat biotic and abiotic stresses-A review. Agric. Rev. 2018, 39, 1-11. [CrossRef]

22. Colla, G.; Rouphael, Y.; Cardarelli, M.; Rea, E. Effect of salinity on yield, fruit quality, leaf gas exchange, and mineral composition of grafted watermelon plants. Hort. Sci. 2006, 41, 622-627. [CrossRef]

23. Krumbein, A.; Schwarz, D. Grafting: A possibility to enhance health-promoting and flavor compounds in tomato fruits of shaded plants? Sci. Hortic. 2013, 149, 97-107. [CrossRef]

24. Suchoff, D.H.; Gunter, C.C.; Louws, F.J. Comparative analysis of root system morphology on tomato rootstock. HortTechnology 2017, 27, 319-324. [CrossRef]

25. Rysin, O.; Louws, F.J. Decision tool for growers to evaluate economic impact of grafting technology adoption: An application to open-field conventional tomato production. HortTechnology 2015, 25, 132-138. [CrossRef] 